Manuscript submitted to Dalton Transactions.

\title{
Deprotonation/protonation of coordinated secondary thioamide units of pincer ruthenium complexes: Modulation of voltammetric and spectroscopic characterization of the pincer complexes
}

\author{
Takuya Teratani, ${ }^{a}$ Take-aki Koizumi, ${ }^{a}{ }^{a}$ Takakazu Yamamoto, ${ }^{a}$ Koji Tanaka, ${ }^{b}$ and \\ Takaki Kanbara $* c, d$
}

Received XX XXXXX 2010, Accepted XX XXXXX 2010

Abstract: New pincer ruthenium complexes, $[\mathrm{Ru}(\mathrm{SCS})(\mathrm{tpy})] \mathrm{PF}_{6} \quad(\mathbf{1}) \quad(\mathrm{SCS}=$ 2,6-bis(benzylaminothicarbonyl)phenyl, tpy $\quad=\quad 2,2^{\prime}: 6^{\prime}, 2^{\prime \prime}$-terpyridyl) and $[\mathrm{Ru}(\mathrm{SNS})(\mathrm{tpy})] \mathrm{PF}_{6}(\mathbf{2})$ (SNS = 2,5-bis(benzylaminothiocarbonyl)pyrrolyl), having the $\kappa^{3}$ SCS and $\kappa^{3}$ SNS pincer ligands with two secondary thioamide units were synthesized by the reactions of $\left[\mathrm{RuCl}_{3}(\mathrm{tpy})\right]$ with $N, N$-dibenzyl-1,3-benzenedicarbothioamide (L1) and $N, N$-dibenzyl-2,5-1H-pyrroledicarbothioamide (L2), respectively, and their chemical and electrochemical properties were elucidated. The structure of $\mathbf{1}$ was determined by X-ray crystallography. The complexes $\mathbf{1}$ and $\mathbf{2}$ showed a two-step deprotonation reaction by treatment with 1,8-diazabicyclo[5,4,0]undec-7-ene (DBU), and the addition of DBU led to a shift of the metal-centered redox couples to a lower potential by 720 and $550 \mathrm{mV}$, respectively. The di-deprotonated complexes were also studied by ${ }^{1} \mathrm{H}-\mathrm{NMR}$ and $\mathrm{UV}$-vis spectroscopy. The addition of methanesulfonic acid (MSA) to the di-deprotonated 
complexes enabled the recovery of $\mathbf{1}$ and $\mathbf{2}$, indicating that the thioamide moiety underwent a reversible deprotonation-protonation process, which resulted in regulating the redox potentials of the metal center. The Pourbaix diagram of $\mathbf{1}$ revealed that $\mathbf{1}$ underwent a one-proton/one-electron transfer process in the $\mathrm{pH}$ range of 5.83-10.35, and a two-proton/one-electron process at a $\mathrm{pH}$ of over 10.35, indicating that the deprotonation/protonation process of the complexes is related to proton-coupled electron transfer (PCET).

\section{Introduction}

The study of secondary thioamides has been the subject of recent interest, ${ }^{1}$ because the $\mathrm{N}-\mathrm{H}$ proton of secondary thioamides exhibits strong hydrogen donor ability, ${ }^{2}$ whereas the sulfur atom of thioamide is dominant as a Lewis base donor for soft transition-metal coordination. ${ }^{3}$ The characteristics of thioamide are reflected by the results of a number of recent applied studies of anion reception ${ }^{4}$ and transition-metal-ion coordination chemistry. $^{5-7}$ Bowman-James's group and our group previously reported that thioamide-based pincer complexes are photoluminescent and have catalytic activity. ${ }^{6,7}$ As an extension of this research, we here report results of the modulation of the electronic properties of the metal center of the following $\mathrm{Ru}(\mathrm{II})$ complexes by deprotonation-protonation reactions of the $-\mathrm{NH}-$ groups in the secondary thioamide ligand.

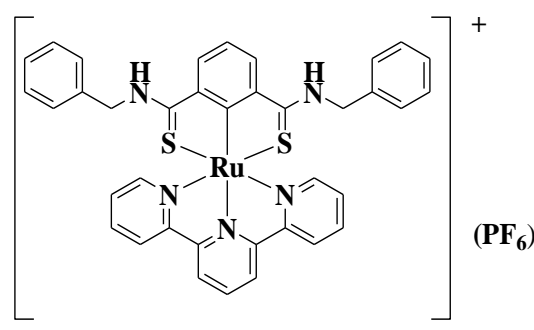

1

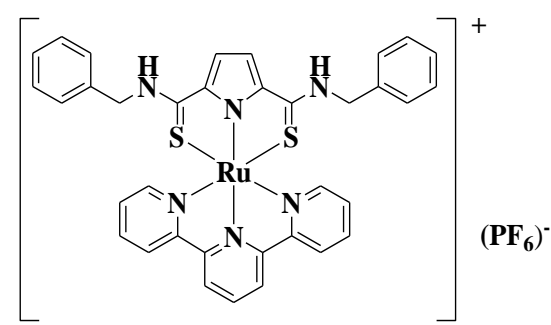

2 
The secondary thioamide group is in equilibrium with its amino-thione and imino-thiol tautomers as shown in Scheme $1,{ }^{3 \mathrm{~d}}$ and exhibits stronger acidity than the corresponding amide group. ${ }^{2}$ Consequently, when secondary thioamides are used as ligands in metal complexes, they are easily deprotonated to give their thionate anionic form, which enhances the donor capability of the sulfur atom via the N-to-S backbone. ${ }^{3 d, e, 7 e}$

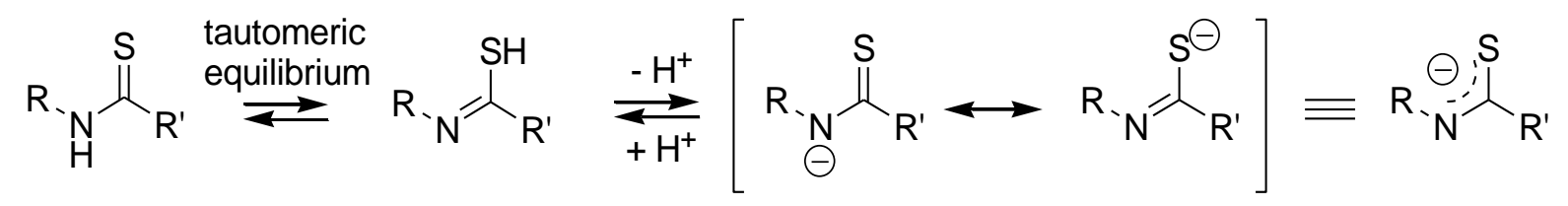

amino-thione

imino-thiol

thionate anion

Scheme 1. Equilibria and structures of a secondary thioamide group in neutral and basic solutions

This situation prompted us to utilize the secondary thioamide group as not only a coordination site but also a reactive site on the ligand of the pincer complex. Actually, the modulation of the photochemical properties of the pincer platinum and palladium complexes could be achieved upon exposure to chemical stimuli. ${ }^{7 e, g}$ In this paper, we report new pincer ruthenium complexes, $\mathbf{1}$ and $\mathbf{2}$, with two coordinated secondary thioamide units. The electronic properties of the complexes were expected to be modulated by the acid-base environment of the media because many elegant reports on the acid-base properties of multi-nitrogen ligated ruthenium complexes ${ }^{8}$ as well as on the voltammetric characterizations of various pincer ruthenium complexes have been published. ${ }^{9} \quad$ The spectroscopic characterization and molecular structures of the complexes are also presented. 


\section{Results and discussion}

\section{Preparation and characterization of Ru-pincer complexes}

The Ru complexes 1 and 2 were prepared by the reaction of $\mathrm{AgPF}_{6}$-treated $\left[\mathrm{RuCl}_{3}(\mathrm{tpy})\right]$ with $\mathbf{L} 1$ and L2, respectively, in 2-methoxyethanol under $\mathrm{N}_{2}$ as shown in Scheme 2. The complexes obtained are stable in air they were characterized by NMR spectroscopy and ESI-MS spectroscopy. In the ${ }^{1} \mathrm{H}-\mathrm{NMR}$ spectra of $\mathbf{1}$ and $\mathbf{2}$, the $\mathrm{N}-\mathrm{H}$ proton signals were observed at $\delta 9.22$ and 8.87 , respectively; the complexation caused a downfield shift of the signal by 0.14 and $0.01 \mathrm{ppm}$ from the corresponding free ligands, respectively.

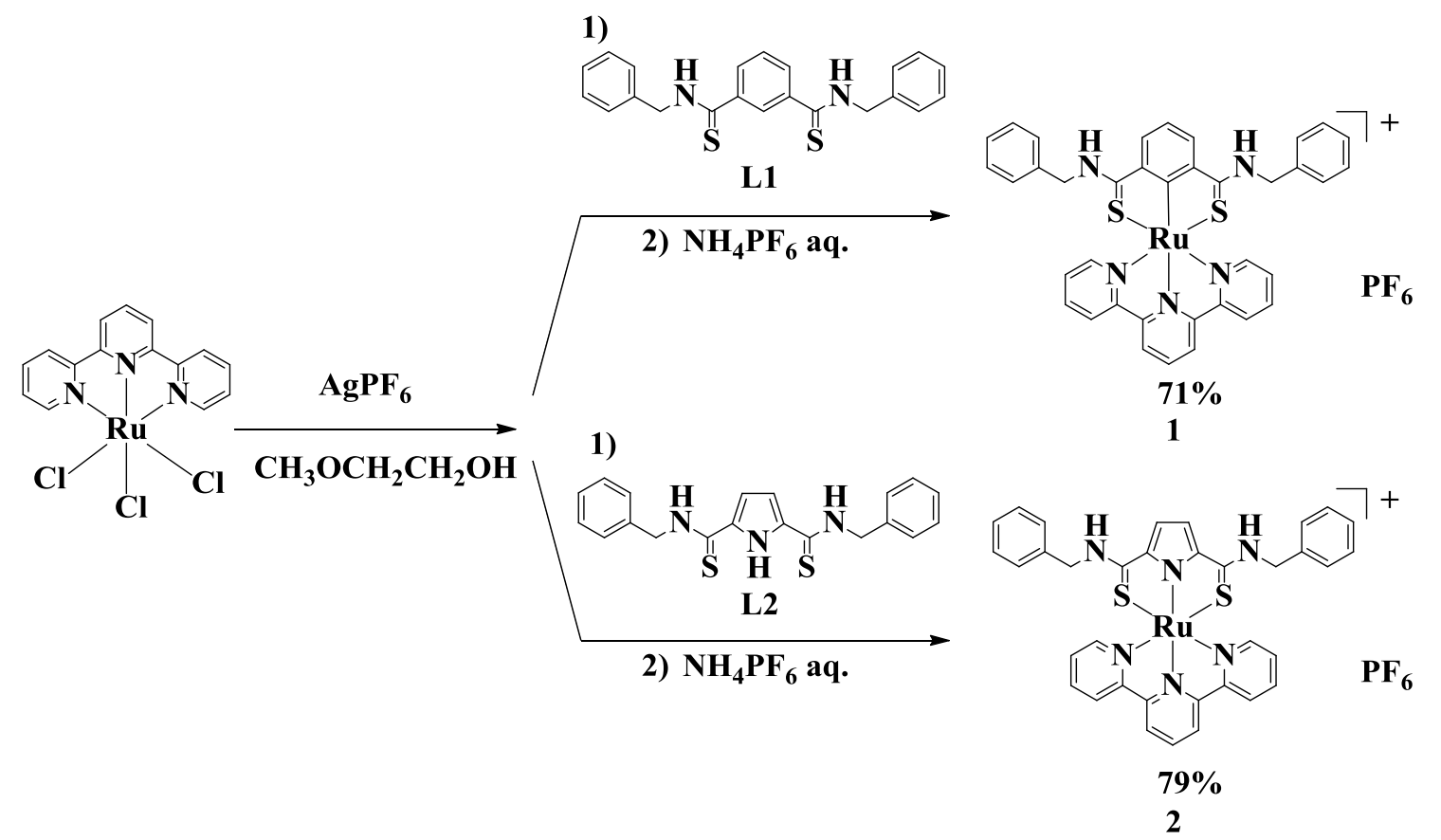

Scheme 2. Synthetic routes to complexes 1 and 2.

The ESI-MS spectra of 1 and 2 showed parent peaks at $m / z=710$ and 699, respectively, indicating that these complexes were monocationic and that the $\mathrm{Ru}$ centers of the 
complexes were divalent.

Fig. 1 shows the ORTEP drawing of the cationic part of $\mathbf{1}$, and selected bond lengths and angles of $\mathbf{1}$ are summarized in Table 1. As shown in Fig. 1, $\mathbf{1}$ has a distorted octahedral geometry similar to that of $\left[\mathrm{Ru}(\mathrm{tpy})_{2}\right]^{2+},{ }^{10}$ and the Ru1-C1 bond length of $\mathbf{1}$ is in the range of those previously reported for pincer Ru complexes. ${ }^{9 b, 11}$ Sums of the bond angles around the $\mathrm{N} 1$ and $\mathrm{N} 2$ atoms are 359.7 and $359.8^{\circ}$, respectively, which have almost planar structures.

\section{Electrochemical properties}

Electrochemical data of $\mathbf{1}$ and $\mathbf{2}$ are summarized in Table 2. The cyclic voltammogram $(\mathrm{CV})$ of 1 exhibited three reversible redox couples at $E_{1 / 2}=+0.825,+0.028$ and $-2.365 \mathrm{~V}$ (vs. $\mathrm{Fc}^{+} / \mathrm{Fc}$ ) in acetonitrile under $\mathrm{N}_{2}$. These are assigned to the metal-centered $\mathrm{Ru}(\mathrm{IV}) / \mathrm{Ru}(\mathrm{III})$ and $\mathrm{Ru}(\mathrm{III}) / \mathrm{Ru}(\mathrm{II})$ couples and a ligand-localized couple, respectively. Owing to the $\sigma$-donor character of the pincer ligand, ${ }^{9 \mathrm{~d}, 12}$ the metal-centered oxidation of $\mathbf{1}$ $\left(\mathrm{Ru}(\mathrm{III}) / \mathrm{Ru}(\mathrm{II}) ; E_{1 / 2}=+0.028 \mathrm{~V}\right)$ occurs at a lower oxidation potential than those of conventional $\mathrm{Ru}$ complexes such as $\left[\mathrm{Ru}(\mathrm{bpy})_{3}\right]^{2+}\left(E_{1 / 2}=+0.88 \mathrm{~V} \quad v s . \mathrm{Fc}^{+} / \mathrm{Fc}\right)$ and $\left[\mathrm{Ru}(\mathrm{tpy})_{2}\right]^{2+}\left(E_{1 / 2}=+0.92 \mathrm{~V} \text { vs. } \mathrm{Fc}^{+} / \mathrm{Fc}\right)^{7,}{ }^{72}$ The $\mathrm{Ru}(\mathrm{III}) / \mathrm{Ru}(\mathrm{II})$ response of 2 was observed at $E_{1 / 2}=+0.088 \mathrm{~V}$, which is $0.06 \mathrm{~V}$ higher than that of $\mathbf{1}$. This result indicates that the electron-donating ability of the pincer ligand of $\mathbf{1}$ is higher than that of $\mathbf{2 .}^{13}$ Moreover, from the comparison of other ruthenium complexes shown in Table 2, the redox potential of $\mathrm{Ru}(\mathrm{III}) / \mathrm{Ru}(\mathrm{II})$ of $\mathbf{1}$ is higher than that of $[\mathrm{Ru}(\mathrm{NCN})(\mathrm{tpy})]^{+}(\mathrm{NCN}=$ $\left.\left[\mathrm{C}_{6} \mathrm{H}_{3}\left(\mathrm{CH}_{2} \mathrm{NMe}_{2}\right)_{2}-2,6\right]^{-}\right)^{9 \mathrm{~b}}$ (cf. Scheme 3) and lower than that of $[\mathrm{Ru}(\mathrm{PCP})(\mathrm{tpy})]^{+}(\mathrm{PCP}=$ $\left.\left[\mathrm{C}_{6} \mathrm{H}_{3}\left(\mathrm{CH}_{2} \mathrm{PPh}_{2}\right)_{2}-2,6\right]^{-}\right),{ }^{9 b}$ suggesting that the donation/back-donation ability of the 
thiocarbonyl group in the thioamide moiety is between those of amine and phosphine.

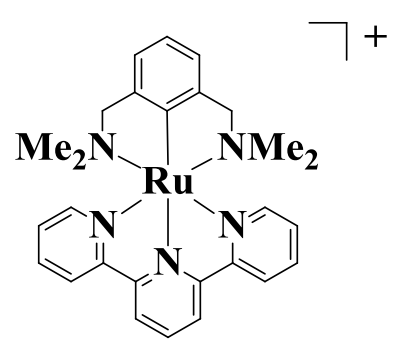

(a)

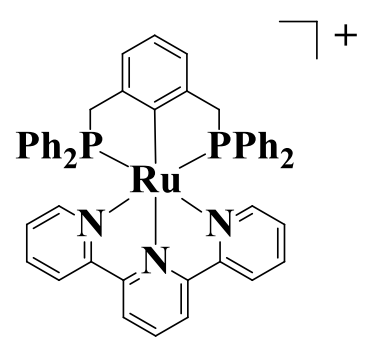

(b)

Scheme 3. Structures of (a) $[\mathrm{Ru}(\mathrm{NCN})(\mathrm{tpy})]^{+}$and (b) $[\mathrm{Ru}(\mathrm{PCP})(\mathrm{tpy})]^{+}$.

The influence of deprotonation of the coordinated pincer ligand on the redox potential of the Ru center was examined by $\mathrm{CV}$ with the addition of a controlled amount of the base (Table 3). Fig. 2 shows the $\mathrm{CV}$ curves of $\mathbf{1}, \mathbf{1}$ with 2.00 equiv of $\mathrm{NEt}_{3}\left(\mathrm{p} K_{\mathrm{a}}=18.82\right.$ in $\mathrm{CH}_{3} \mathrm{CN}$ ), and 1 with 2.00 equiv of $\mathrm{DBU}\left(\mathrm{p} K_{\mathrm{a}}=24.34 \text { in } \mathrm{CH}_{3} \mathrm{CN}\right)^{13}$ in the region of +0.1 to $-1.2 \mathrm{~V}\left(v s . \mathrm{Fc}^{+} / \mathrm{Fc}\right)$. When $\mathrm{NEt}_{3}$ is added to $\mathbf{1}$, the observed currents based on the $\mathrm{Ru}(\mathrm{III}) / \mathrm{Ru}(\mathrm{II})$ redox couple of $\mathbf{1}$ at $E_{1 / 2}=+0.028 \mathrm{~V}$ is gradually decreased and a new redox couple appears at $E_{1 / 2}=-0.226 \mathrm{~V}$. Upon addition of 2.00 equiv of $\mathrm{NEt}_{3}$, the redox couple at $E_{1 / 2}=+0.028 \mathrm{~V}$ disappears completely (Fig. 2(b)). The newly appearing redox couple is considered to be associated with the $\mathrm{Ru}(\mathrm{III}) / \mathrm{Ru}(\mathrm{II})$ response of $\mathbf{3}$, which is a mono-deprotonated form of $\mathbf{1}$ as shown in Scheme 4. In contrast, the addition of DBU led to the consecutive deprotonation of $\mathbf{1}$. When DBU was added to $\mathbf{1}$ (>2 mol equiv), the original $\mathrm{Ru}(\mathrm{III}) / \mathrm{Ru}(\mathrm{II})$ redox couple decreased in amount and two new redox couples at $E_{1 / 2}$ $=-0.226 \mathrm{~V}$ and $-0.692 \mathrm{~V}\left(v s . \mathrm{Fc}^{+} / \mathrm{Fc}\right)$ appeared. After the addition of $2.00 \mathrm{~mol}$ equiv of $\mathrm{DBU}$, the redox couple at $E_{1 / 2}=-0.226 \mathrm{~V}$ disappeared completely and only one redox couple at $E_{1 / 2}=-0.692 \mathrm{~V}$ was observed. The latter redox couple is assigned to the 
$\mathrm{Ru}(\mathrm{III}) / \mathrm{Ru}(\mathrm{II})$ redox couple of the di-deprotonated complex 4 as shown in Scheme 4 . When 2.00 equiv of methanesulfonic acid (MSA) was added to 4, the redox couple observed at $E_{1 / 2}=-0.692 \mathrm{~V}\left(v s . \mathrm{Fc}^{+} / \mathrm{Fc}\right)$ disappeared and the redox couple at $E_{1 / 2}=-0.028 \mathrm{~V}\left(v s . \mathrm{Fc}^{+} / \mathrm{Fc}\right)$ reappeared. This result indicates that the di-deprotonated complex $\mathbf{4}$ is converted smoothly to 1 by the addition of the protic acid, and the clean conversion between the protonated and deprotonated forms regulates the redox potential of the $\mathrm{Ru}(\mathrm{III}) / \mathrm{Ru}(\mathrm{II})$ couple by $720 \mathrm{mV}$, which is much larger than the shift in the redox potential reported for the $\mathrm{Ru}$ complexes bearing multi-nitrogen ligands. ${ }^{8}$ The metal-centered redox couples of $\mathbf{1}, \mathbf{3}$, and $\mathbf{4}$ were essentially unchanged in repeated scans under $\mathrm{N}_{2}$, and no electrochemical response occurring at the ligand or the added base was observed in the scan range.

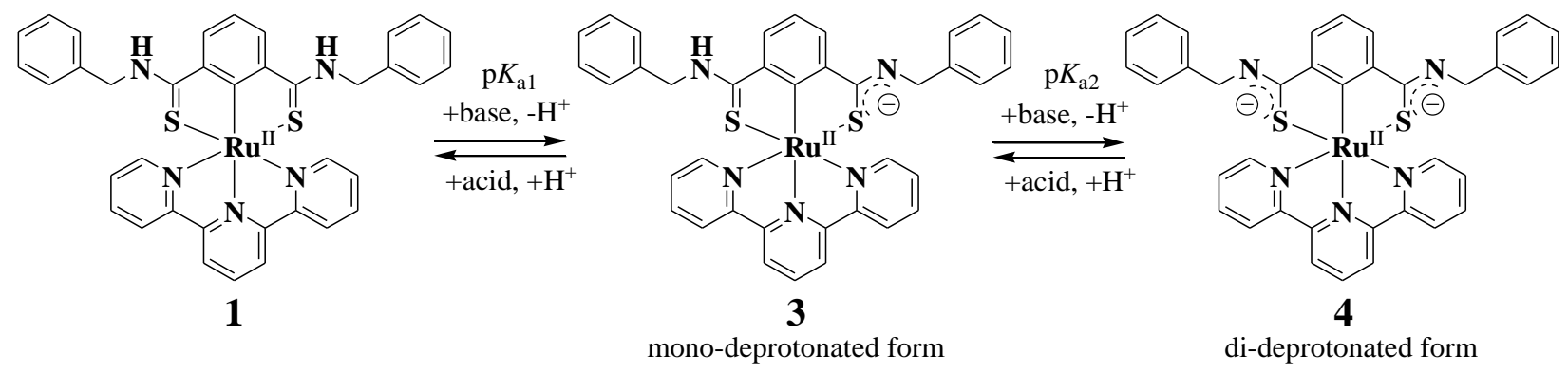

Scheme 4. Deprotonation-protonation reaction of 1.

A similar reversible deprotonation-protonation was observed in $\mathbf{2}$, and the difference in redox potential between 2 and di-deprotonated 2 was $550 \mathrm{mV}$. As a control experiment, a pincer $\mathrm{Ru}$ complex bearing two tertiary thioamide groups, 5 (shown in Scheme 5), was prepared and its redox potentials under conditions of added base were observed. 


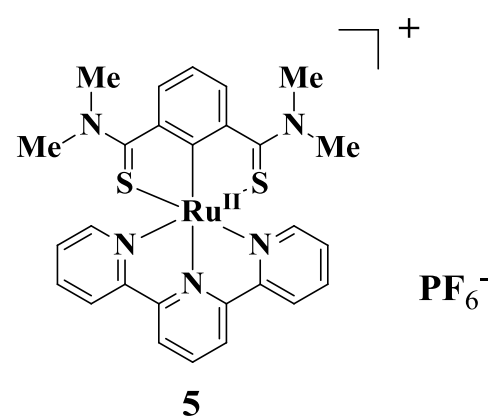

Scheme 5. Molecular structure of 5.

As a result, 5 was electrochemically stable under basic conditions (see Fig. S1), indicating that the incorporation of secondary thioamide groups in $\mathbf{1}$ and $\mathbf{2}$ is necessary to control the redox potentials of the complex by acid/base treatment.

\section{Spectroscopic study of 1 with added base}

The reversible deprotonation-protonation behavior of $\mathbf{1}$ was also monitored by ${ }^{1} \mathrm{H}$ NMR, ESI-MS, and UV-vis spectroscopy. The ${ }^{1} \mathrm{H}$ NMR spectra of $\mathbf{1}, \mathbf{1}$ with 2.00 mol equiv of $\mathrm{NEt}_{3}$, and $\mathbf{1}$ with 2.00 mol equiv of DBU are shown in Fig. S2. When excess DBU was added to $\mathbf{1}$, the $\mathrm{N}-\mathrm{H}$ proton signal of $\mathbf{1}$ at $\delta 9.22$ completely disappeared, and significant upfield shifts of the aromatic signals were observed. The newly generated compound is considered to be the di-deprotonated complex 4. The addition of an excess amount of MSA to the DBU-treated solution caused the signals of $\mathbf{1}$ to recover completely.

The ESI-MS spectrum of DBU-treated 1 showed a parent peak at $\mathrm{m} / z=708$ in the negative-ionization mode, and no peaks for a dinuclear complex or larger clusters were found in the mass spectra under basic conditions.

In the UV-vis absorption spectrum of $\mathbf{1}$ in $\mathrm{CH}_{3} \mathrm{CN}$, broadened absorption bands at $\lambda_{\max }=$ $420 \mathrm{~nm}$ and $\lambda_{\max }=495 \mathrm{~nm}$ with a shoulder peak at $550 \mathrm{~nm}$ were observed. Assignments of the $\pi-\pi^{*}$ transition and the MLCT absorption bands were made by time-dependent 
density functional theory (TD-DFT) calculations of the complex. ${ }^{14}$ Table 4 shows the oscillator strengths and corresponding assignments of the primary electronic transitions. Three-dimensional plots of the HOMOs and LUMOs of $\mathbf{1}$ and their molecular orbitals (MOs) are shown in Fig. 3 using GaussView 4.1. ${ }^{15}$ From the TD-DFT calculation, 1 has two strong MLCT transitions originating from HOMO -2 to LUMO at $474 \mathrm{~nm}$ and from HOMO -1 to LUMO +3 at $401 \mathrm{~nm}$. For 1, the LUMO consisting of $\pi^{*}$ orbitals is from the thioamide ligand, while LUMO +3 is from the tpy ligand. The HOMO -1 and HOMO -2 are pure d orbitals of the central metal. Two transitions at $\lambda_{\max }=474 \mathrm{~nm}$ and $401 \mathrm{~nm}$ are assigned to the metal-to-ligand charge transfer (MLCT) contributed by the thioamide ligand and tpy unit, respectively. These assignments are in agreement with other previously reported $\mathrm{Ru}(\mathrm{II})$ complexes containing tpy ligands. ${ }^{8,9}$

The UV-vis spectrum of $\mathbf{1}$ is changed by the addition of DBU, as shown in Fig. 4. The increase in the amount of DBU caused a decrease in the area of the original peak of $\mathbf{1}$, and the area of a new absorption band peak at $\lambda_{\max }=565 \mathrm{~nm}$ increased with an isosbestic point at $532 \mathrm{~nm}$. The absorbance of the new peak at $\lambda_{\max }=565 \mathrm{~nm}$ saturates at a DBU/1 ratio of 2.00, indicating that the deprotonation of $\mathbf{1}$ proceeds consecutively to give the di-deprotonated complex 4. The addition of MSA to the solution of 4 led to an immediate recovery of $\mathbf{1}$. When excess $\mathrm{NEt}_{3}$ was used as a base instead of DBU, the ${ }^{1} \mathrm{H} \mathrm{NMR}$, ESI-MS, and UV-vis spectra of $\mathbf{1}$ were almost unchanged, even though the CV of $\mathbf{1}$ changed under the same conditions. These inconsistent results suggest that the mono-deprotonation of $\mathbf{1}$ by the addition of $\mathrm{NEt}_{3}$ proceeded by the electro-oxidation of the central $\mathrm{Ni}$ atom. 


\section{Study of proton-coupled electron transfer (PCET) process in 1.}

In an electrochemical reaction mechanism, the simultaneous transfer of electrons and protons is called PCET. ${ }^{8 \mathrm{a}}$ From the experiments using $\mathrm{NEt}_{3}$ the deprotonation/protonation of N-H protons is considered to take place via PCET. Many complexes containing ionizable protons in ligands were reported to undergo PCET. Kojima et al. revealed the PCET reaction of the $\mathrm{Ru}$ complex containing two amide groups; ${ }^{8 \mathrm{e}}$ the reversible deprotonation-protonation of the N-H group of coordinated secondary amides can control the redox potential of the ruthenium center markedly by approximately $500 \mathrm{mV}$. The redox potentials of $\mathbf{1}$ in $\mathrm{pH}-$-controlled solutions (solvent: MeCN-Robinson-Britton buffer $(1: 1 \mathrm{v} / \mathrm{v}))$ were monitored by $\mathrm{CV}$. Fig. 5 shows the $\mathrm{pH}$-dependent $\mathrm{CV}$ curves of $\mathbf{1}$ in the $\mathrm{pH}$ range of 2.18-12.15. With an increase in $\mathrm{pH}$, the $E_{1 / 2}$ potential of the $\mathrm{Ru}(\mathrm{III}) / \mathrm{Ru}(\mathrm{II})$ is shifted successively to negative potentials. This result indicates that the deprotonation reaction of $\mathbf{1}$ takes place via PCET. The resultant Pourbaix diagram ${ }^{8 \mathrm{a}-\mathrm{c}, \mathrm{e}}$ is shown in Fig. 6. Plots in Fig. 6 illustrate two different PCET processes taking place. The gradient of the linear relationship between $\mathrm{pH}$ and $E_{1 / 2}$ for the $\mathrm{Ru}(\mathrm{III}) / \mathrm{Ru}(\mathrm{II})$ redox couple is determined to be $-56.4 \mathrm{~V} / \mathrm{pH}$ in the $\mathrm{pH}$ range of $5.83-10.35$, which relates well to the expected value for a one-electron/one-proton process, ${ }^{8 a, 8 g}$ as shown in Scheme 6(a). 
(a) $5.83<\mathrm{pH}<10.35$

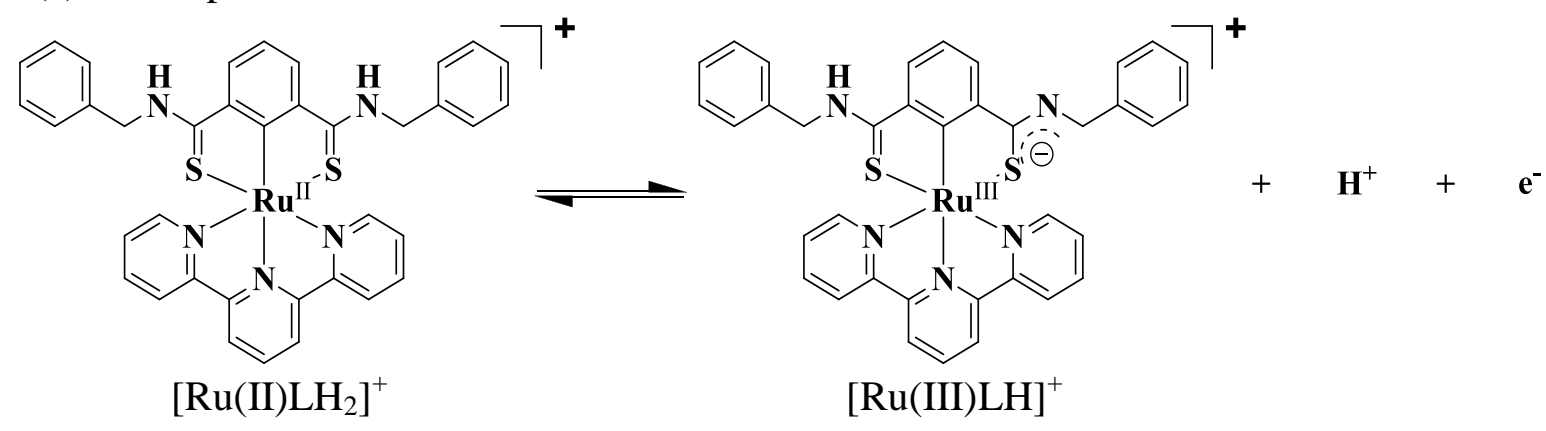

(b) $10.35<\mathrm{pH}$

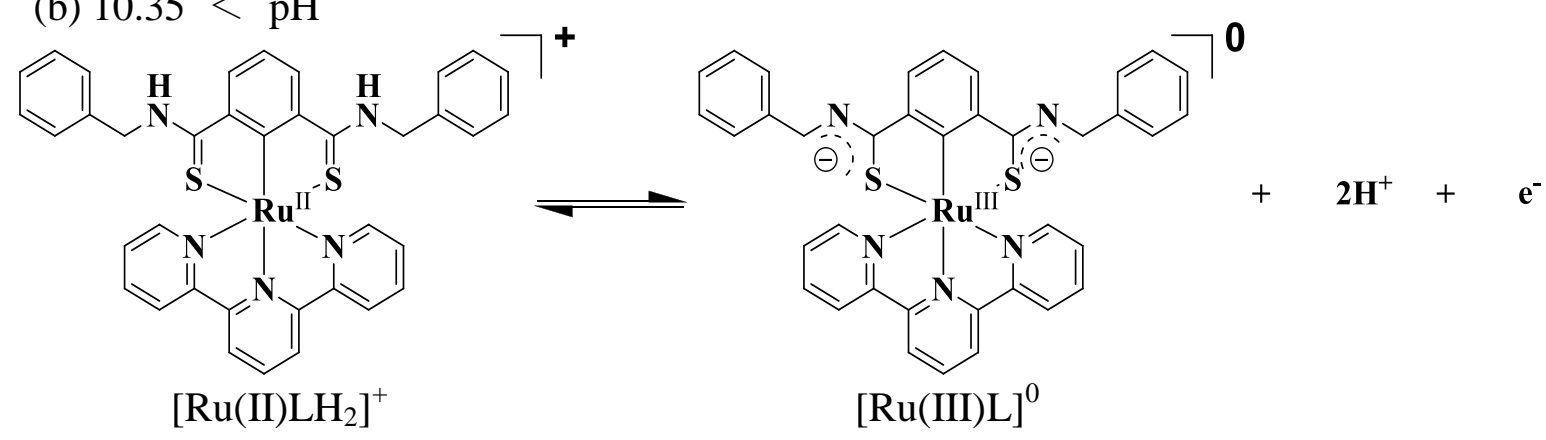

Scheme 6. Proton-coupled electron transfer reaction of $\mathbf{1}$ in two different $\mathrm{pH}$ ranges.

The slope increases to $-117.3 \mathrm{mV} / \mathrm{pH}$ at a $\mathrm{pH}$ of over 10.35 , and the slope is close to that expected for a one-electron/two-proton transfer, as shown in Scheme 6(b). Under these conditions, we could not observe the $[\mathrm{Ru}(\mathrm{II}) \mathrm{LH}]^{0}-[\mathrm{Ru}(\mathrm{III}) \mathrm{L}]^{0}$ or $[\mathrm{Ru}(\mathrm{II}) \mathrm{L}]^{-}-[\mathrm{Ru}(\mathrm{III}) \mathrm{L}]^{0}$ process in the $\mathrm{pH}$ range of 2.18-12.15. These results suggest that the reversible deprotonation/protonation process of secondary thioamides in the pincer ligand can control the redox potential of the Ru center in the range of ca. $500 \mathrm{mV}$.

\section{Conclusions}

We have synthesized new SCS- and SNS-pincer Ru complexes containing secondary thioamide units in the pincer ligand and characterized their chemical and electrochemical properties. The electrochemical behavior of the complexes suggests that the electron 
donating ability of the benzene-centered pincer ligand is higher than that of the pyrrole-centered one, which is similar to the behavior of SCS- and SNS- pincer Ni complexes. Deprotonation/protonation reaction of N-H protons in $\mathbf{1}$ and $\mathbf{2}$ using acid/base can regulate the redox potentials of the complexes in the range of 550-720 $\mathrm{mV}$. The redox regulations of $\mathbf{1}$ and $\mathbf{2}$ with acid/base suggest that the catalytic activity of reactions using a redox process could be adjusted. ${ }^{16}$ The PCET process of $\mathbf{1}$ was examined by $\mathrm{pH}$-dependent cyclic voltammetry. In the MeCN-buffer solution, one-electron/one-proton transfer is exhibited in the $\mathrm{pH}$ range of 5.83-10.35, and one-electron/two proton transfer is observed at $\mathrm{pH}>10.35$. 


\section{Experimental Section}

General methods. ${ }^{1} \mathrm{H}-\mathrm{NMR}$ spectra were recorded on a JNM EX-300 or an EX-270 spectrometer. Chemical shifts $(\delta, \mathrm{ppm})$ were reported with reference to TMS. UV-vis spectra were measured with a Shimadzu UV-2550 UV-visible spectrophotometer. Elemental analyses were carried out with a Yanaco MT-5 CHN autorecorder. Electrochemical measurements were performed with a BAS ALS 1200A automatic polarization system. A conventional three-electrode configuration was used, with glassy carbon working electrode (BAS electrode) and a platinum wire auxiliary electrode (The Nilaco Corp., special order) and 0.01 $\mathrm{M} \mathrm{AgNO}_{3} / \mathrm{Ag}$ as reference (BAS RE-5). Cyclic voltammograms were recorded at a scan rate of $100 \mathrm{mV} \mathrm{s}^{-1}: \mathrm{Fc}^{+} / \mathrm{Fc}=+115 \mathrm{mV}$ vs. $0.10 \mathrm{M}$ $\mathrm{AgNO}_{3} / \mathrm{Ag}$, and $+425 \mathrm{mV}$ vs. SCE. The Pourbaix diagram was obtained by measurements of $E_{1 / 2}$ values through $\mathrm{pH}$ titration by saturated $\mathrm{NaOH}$ aqueous solutions in a $\mathrm{CH}_{3} \mathrm{CN} /$ Britton-Robinson buffer $(1: 1 \mathrm{v} / \mathrm{v})$ mixture at room temperature. The apparent $\mathrm{pHs}$ of this mixture are referred to as $\mathrm{pH}$. ESI-MS spectra were obtained with a Waters-Micro-massLCT. [RuCl ${ }_{3}$ (tpy) $]^{17}$, 1,3-bis(benzylaminothiocarbonyl)benzene $(\mathbf{L} \mathbf{1})^{7 \mathrm{~d}}$, 2,5-bis(benzylaminothiocarbonyl)pyrrole $(\mathbf{L} 2)^{7 \mathrm{~d}}$ and 1,3-bis(dimethylaminothiocarbonyl)benzene ${ }^{7 \mathrm{~b}}$ were prepared according to the literature methods.

\section{$\left[\operatorname{Ru}\left(\operatorname{SCS}_{-B n_{2}}\right)\left(\operatorname{tpy}_{)}\right] \mathrm{PF}_{6}(1)\right.$.}

To a $\mathrm{CH}_{3} \mathrm{OCH}_{2} \mathrm{CH}_{2} \mathrm{OH}$ solution $\left(20 \mathrm{~mL}\right.$ ) of $\left[\mathrm{RuCl}_{3}\right.$ (tpy)] (400 mg, $0.90 \mathrm{mmol}$ ) was added $\mathrm{AgPF}_{6}(460 \mathrm{mg}, 1.40 \mathrm{mmol})$ and the resulting mixture was stirred at $75^{\circ} \mathrm{C}$ for $2 \mathrm{~h}$. The resulting off-white solid was eliminated by celite filtration. L1 (344 mg, $0.92 \mathrm{mmol}$ ) was added to the violet filtrate and the reaction mixture was stirred at $75^{\circ} \mathrm{C}$ for $12 \mathrm{~h}$. The 
solution was concentrated to ca. $1 \mathrm{~mL}$ and poured into aqueous $\mathrm{NH}_{4} \mathrm{PF}_{6}$. The resulting violet solid was collected by filtration, dried in vacuo, and recrystallized from ether/acetone to give $\mathbf{1}$ (349 mg, 44\%) as deep purple needles (Found: C, 51.56; H, 3.80; $\mathrm{N}$, 7.87. Calc. for $\mathrm{C}_{37} \mathrm{H}_{30} \mathrm{~F}_{6} \mathrm{~N}_{5} \mathrm{PRuS}_{2}$ : C, 51.99; H, 3.54; N, 8.19\%); $\delta_{\mathrm{H}}(300 \mathrm{MHz}$; acetonitrile- $\left.d_{3}\right) 9.22(2 \mathrm{H}, \mathrm{s}, \mathrm{N} H), 8.45(2 \mathrm{H}, \mathrm{d}, J 8.1), 8.23(2 \mathrm{H}, \mathrm{d}, J 6.75), 8.05(1 \mathrm{H}, \mathrm{t}, J$ 7.6), $7.70(2 \mathrm{H}, \mathrm{td}, J 7.8$ and 1.6), $7.31(1 \mathrm{H}, \mathrm{t}, J$ 7.8), 7.22-7.19 (10 H), $7.05(2 \mathrm{H}, \mathrm{t}, J$ 6.48), 6.96 (2 H, d, J 4.8), $4.86\left(4 \mathrm{H}, \mathrm{d}, J\right.$ 5.9); $\mathrm{m} / z$ (ESI) $710\left(\mathrm{M}^{+} . \mathrm{C}_{37} \mathrm{H}_{30} \mathrm{~N}_{5} \mathrm{RuS}_{2}\right.$ requires 710.10).

\section{$\left[\operatorname{Ru}\left(\mathrm{SNS}_{\mathbf{B}} \mathrm{Bn}_{2}\right)\left(\mathrm{tpy}_{)}\right] \mathrm{PF}_{6}(2)\right.$.}

Method A:

To a $\mathrm{CH}_{3} \mathrm{OCH}_{2} \mathrm{CH}_{2} \mathrm{OH}$ solution $(20 \mathrm{~mL})$ of $\left[\mathrm{RuCl}_{3}(\mathrm{tpy})\right](50 \mathrm{mg}, 0.114 \mathrm{mmol})$ was added L2 (42 mg, $0.114 \mathrm{mmol}$ ) and triethylamine (2 mL), and the resulting mixture was stirred at $75^{\circ} \mathrm{C}$ for $12 \mathrm{~h}$. The solution was concentrated to ca. $1 \mathrm{~mL}$, and poured into aqueous $\mathrm{NH}_{4} \mathrm{PF}_{6}$. The resulting deep red solid was collected by filtration and dried in vacuo (56 $\mathrm{mg}, 40 \%)$.

Method B:

To a $\mathrm{CH}_{3} \mathrm{OCH}_{2} \mathrm{CH}_{2} \mathrm{OH}$ solution $(20 \mathrm{~mL})$ of $\left[\mathrm{RuCl}_{3}(\mathrm{tpy})\right](100 \mathrm{mg}, 0.23 \mathrm{mmol})$ was added $\mathrm{AgPF}_{6}(115 \mathrm{mg}, 0.35 \mathrm{mmol})$, and the resulting mixture was stirred at $75^{\circ} \mathrm{C}$ for $2 \mathrm{~h}$. The resulting off-white solid was eliminated by celite filtration, and $\mathbf{L 2}$ (83 $\mathrm{mg}, 0.23 \mathrm{mmol}$ ) was added to the violet filtrate. The mixture was stirred at $75^{\circ} \mathrm{C}$ for $12 \mathrm{~h}$. The solution was concentrated to ca. $1 \mathrm{~mL}$ and poured into aqueous $\mathrm{NH}_{4} \mathrm{PF}_{6}$. The resulting deep red solid was collected by filtration, dried in vacuo, and recrystallized from ether/acetone to give 2 (153 mg, 79\%) as deep red needles (Found: C, 49.44; H, 3.46; N, 9.61. Calc. for 
$\mathrm{C}_{35} \mathrm{H}_{29} \mathrm{~F}_{6} \mathrm{~N}_{6} \mathrm{PRuS} \mathrm{PR}_{2}$ : C, 49.82; H, 3.46; N, 9.96\%.); $\delta_{\mathrm{H}}\left(270 \mathrm{MHz}\right.$, acetonitrile- $\left.d_{3}\right) 8.87(2 \mathrm{H}$, s, NH), $8.39(2 \mathrm{H}, \mathrm{d}, J$ 8.1), $8.30(2 \mathrm{H}, \mathrm{d}, J$ 8.1), $7.95(1 \mathrm{H}, \mathrm{t}, J$ 8.0), $7.84(1 \mathrm{H}, \mathrm{td}, J 7.7$ and 1.5), 7.62 (2 H, d, J 5.3), $7.41(2 \mathrm{H}, \mathrm{t}, J$ 5.9), $7.20(12 \mathrm{H}, \mathrm{m}), 4.73(4 \mathrm{H}, \mathrm{s}) ; \mathrm{m} / z(\mathrm{ESI})$ $699\left(\mathrm{M}^{+} . \mathrm{C}_{35} \mathrm{H}_{29} \mathrm{~N}_{6} \mathrm{RuS}_{2}\right.$ requires 699.09).

\section{$\operatorname{Ru}\left(\mathrm{SCS}_{\mathbf{2}}-\mathrm{Me}_{4}\right)(\mathrm{tpy}) \mathrm{PF}_{6}(\mathbf{5})$.}

To a $\mathrm{CH}_{3} \mathrm{OCH}_{2} \mathrm{CH}_{2} \mathrm{OH}$ solution (20 mL) of $\left[\mathrm{RuCl}_{3}\right.$ (tpy) $(150 \mathrm{mg}, 0.34 \mathrm{mmol})$ was added $\mathrm{AgPF}_{6}(172 \mathrm{mg}, 0.68 \mathrm{mmol})$, and the resulting mixture was stirred at $75^{\circ} \mathrm{C}$ for $2 \mathrm{~h}$. The resulting off-white solid was eliminated by celite filtration, and 1,3-bis(dimethylaminothiocarbonyl)benzene was added $(88.2 \mathrm{mg}, 0.35 \mathrm{mmol})$ to the violet filtrate. The mixture was stirred at $75^{\circ} \mathrm{C}$ for $12 \mathrm{~h}$. The solution was concentrated to ca. $1 \mathrm{~mL}$ and poured into aqueous $\mathrm{NH}_{4} \mathrm{PF}_{6}$. The resulting violet solid was collected by filtration, dried in vacuo and recrystallized from ether/acetone to give $\mathbf{5}(91.8 \mathrm{mg}, 37 \%)$ as black solid ( $\delta_{\mathrm{H}}\left(270 \mathrm{MHz}\right.$, acetonitrile- $\left.d_{3}\right) 8.45(2 \mathrm{H}, \mathrm{d}, J$ 8.1), $8.26(2 \mathrm{H}, \mathrm{d}, J$ 8.1), 8.04 (1 H, t, J 8.1), $7.92(2 \mathrm{H}, \mathrm{d}, J 7.9 \mathrm{~Hz}), 7.69(2 \mathrm{H}, \mathrm{td}, J 7.8$ and 1.5), $7.09(3 \mathrm{H}, \mathrm{m}), 6.96(2 \mathrm{H}$, dt, $J 4.8$ and 0.7$), 3.57(12 \mathrm{H}, \mathrm{s})$.

Crystal structure determination. Crystals of $\mathbf{1}$ and $\mathbf{2}$ for X-ray analysis were obtained as described in the preparations. The suitable crystal was mounted on a glass fiber. Data collection for $\mathbf{1}$ and 2 was performed at $-160{ }^{\circ} \mathrm{C}$ on a Rigaku/MSC Saturn CCD diffractometer with graphite monochromated Mo-K $\alpha$ radiation $(\lambda=0.7107 \AA)$. The data were collected to a maximum $2 \theta$ of $55^{\circ}$. A total of 720 oscillation images were collected. A sweep of the data was performed using $\omega$ scans from $-110^{\circ}$ to $70^{\circ}$ in $0.5^{\circ}$ steps at $\chi=45.0^{\circ}$ and $\phi=0.0^{\circ}$. The structures were solved using the CrystalStructure software package. ${ }^{18}$ Atom scattering factors were obtained from the literature. 
Refinements were performed anisotropically for all non-hydrogen atoms by the full-matrix least-square method. Hydrogen atoms except $\mathrm{H} 1$ and $\mathrm{H} 2$ were placed at the calculated positions and were included in the structure calculation without further refinement of the parameters. $\mathrm{H} 1$ and $\mathrm{H} 2$ of $\mathbf{1}$ and $\mathbf{2}$ were determined by difference Fourier mapping and refined isotropically. The residual electron densities were of no chemical significance. The crystal data and processing parameters are summarized in Table 5. Crystallographic data for the structural analysis of $\mathbf{1}$ and $\mathbf{2}$ in CIF format have been deposited with the Cambridge Crystallographic Data Centre under CCDC No. 789412 (1) and 789413 (2), respectively. These data can be obtained free of charge via www.ccdc.cam.ac.uk/conts/retrieving.html (or from the CCDC, 12 Union Road, Cambridge CB2 1EZ, UK; fax: +44 1223 336033; e-mail: deposit@ccdc.cam.ac.uk).

Computational Details. All the DFT calculations reported in this study were carried out using the Gaussian 03 suite of programs. ${ }^{17}$ The geometries of $\mathbf{1}$ were optimized at the B3LYP/LANL2DZ level.

Acknowledgment. The authors are grateful to Dr. K. Okamoto and Dr. J. Kuwabara of our laboratory and Dr. Y. Shimoi of the National Institute of Advanced Industrial Science and Technology (AIST) for their useful discussions and experimental support. The authors are grateful to the Chemical Analysis Center of University of Tsukuba for performing the X-ray crystallography, NMR spectroscopy, and elemental analysis. 


\section{References}

1 (a) T. S. Jagodziński, Chem. Rev., 2003, 103, 197; (b) T. Murai, Top. Curr. Chem., 2005, 251, 247; c) M. Koketsu, H. Ishihara, Curr. Org. Synth., 2007, 4, 15; (d) S. K. Hadjikakou, N. Hadjiliadis, Bioinorg. Chem. Appl., 2006, 1; (e) W. Zhang, M. Shi, Synlett, 2007, 19.

2 (a) D. R. Artis, M. A. Lipton, J. Am. Chem. Soc., 1998, 120, 12200; (b) H.-J. Lee, Y.-S. Choi, K.-B. Lee, J. Park, C.-J. Yoon, J. Phys. Chem. A, 2002, 106, 7010; (c) C. Laurence, C. M. Berthelot, J.-Y. Le Questel, M. J. El Ghomari, J. Chem. Soc. Perkin Trans. 2, 1995, 2075; (d) Y. Inoue, T. Kanbara, T. Yamamoto, Tetrahedron Lett., 2004, 45, 4603; (e) F. G. Bordwell, D. J. Algrim, J. A. Jr. Harrelson, J. Am. Chem. Soc., 1988, 110, 5903.

3 (a) E. S. Raper, Coord. Chem. Rev., 1994, 129, 91; (b) R. W. Kluiber, Inorg. Chem., 1965, 4, 829; (c) F. Berny, F. J. Wipff, Chem. Soc. Perkin Trans. 2, 2001, 73; (d) J. Sola, A. López, R. A. Coxall, W. Clegg, Eur. J. Inorg. Chem., 2004, 4871; e) T. Chivers, A. Downard, M. Parvez, G. Schatte, Organometallics, 2001, 20, 727; (f) R. Kapoor, A. Kataria, P. Venugopalan, P. Kapoor, M. Corbella, M. Rodríguez, L. Romero, A. Llobet, Inorg. Chem., 2004, 43, 6699; (g) R. Kapoor, A. Kataria, P. Kapoor, A. P. S. Pannu, M. S. Hundal, M. Corbella, Polyhedron, 2007, 26, 5131; (h) M. Nonoyama, Transition Met. Chem., 1990, 15, 366; (i) M. Nonoyama, K. Nakajima, M. Kita, Polyhedron, 1995, 14, 1035; (j) S. Takahashi, M. Nonoyama, M. Kita, Transition Met. Chem., 1995, 20, 528; (k) Y. Nojima, M. Nonoyama, K. Nakajima, Polyhedron, 1996, 15, 3795; (1) M. Nonoyama, J. Coord. Chem., 1999, 48, 137; (m) A. Amoedo, M. Graña, J. Martínez, T. Pereira, M. López-Torres, A. Fernández, J. Fernández, J. M Vila, Eur. J. Inorg. Chem., 2002, 613. 4 (a) Y. Inoue, T. Kanbara, T. Yamamoto, Tetrahedron Lett., 2003, 44, 5167; (b) M. A. 
Hossain, S. O. Kang, J. M. Llinares, D. Powell, K. Bowman-James, Inorg. Chem., 2003, 42, 5043; (c) T. Zielińskia, J. Jurczak, Tetrahedron, 2005, 61, 4081; (d) S. J. Coles, P. A. Gale, M. B. Hursthouse, M. E. Light, C. N. Warriner, Supramol. Chem., 2004, 16, 469; (e) A. A. Mohamed, G. S. Masaret, A. H. M. Elwahy, Tetrahedron, 2007, 63, 4000.

5 (a) K. Raouf-Benchekroun, C. Picard, P. Tisnès, L. Cazaux, J. Incl. Phenom. Macrocycl. Chem., 1999, 34, 277; (b) A. Ceresa, E. Pretsch, Anal. Chim. Acta, 1999, 41, 52; (c) K. Belhamel, T. K. D. Nguyen, M. Benamor, R. Ludwig, Eur. J. Inorg. Chem., 2003, 4110; (d) S. Kagaya, E. Sato, I. Masore, K. Hasegawa, T. Kanbara, Chem. Lett., 2003, 32, 622. (e) M. Du, Z.-H. Zhang, Z.-J. Zhao, Q. Xu, Inorg. Chem., 2006, 45, 5785; (f) S. Kagaya, E. Tanaka, N. Kawai, I. Masore, E. Sato, K. Hasegawa, M. Kishi, T. Kanbara, J. Inorg. Organomet. Polym., 2009, 19, 67; (g) S. Kagaya, H. Miyazaki, M. Ito, K. Tohda, T. Kanbara, J. Hazard. Mater., 2010, 175, 1113.

6 (a) R. A. Begum, D. Powell, K. Bowman-James, Inorg. Chem., 2006, 45, 964; (b) M. A. Hossain, S. Lucarini, D. Powell, K. Bowman-James, Inorg. Chem., 2004, 43, 7275.

7 (a) T. Kanbara, K. Okada, T. Yamamoto, H. Ogawa, T. Inoue, J. Organomet. Chem., 2004, 689, 1860; (b) M. Akaiwa, T. Kanbara, H. Fukumoto, T. Yamamoto, J. Organomet. Chem., 2005, 690, 4192; (c) K. Okamoto, T. Kanbara, T. Yamamoto, T. Wada, Organometallics, 2006, 25, 4026; (d) K. Okamoto, T. Kanbara, T. Yamamoto, Chem. Lett., 2006, 35, 558; (e) K. Okamoto, T. Yamamoto, M. Akita, A. Wada, T. Kanbara, Organometallics, 2009, 28, 3307; (f) T. Koizumi, T. Teratani, K. Okamoto, T. Yamamoto, Y. Shimoi, T. Kanbara, Inorg. Chem. Acta, 2010, 363, 2474; (g) Y. Ogawa, A. Taketoshi, J. Kuwabara, K. Okamoto, T. Fukuda, T. Kanbara, Chem. Lett., 2010, 39, 385.

8 (a) S. J. Slattery, J. K. Blaho, J. Lehnes, K. A. Goldsby, Coord. Chem. Rev., 1998, 174, 
391; (b) A. M. Bond, M. Haga, Inorg. Chem., 1986, 25, 4507; (c) M. Haga, T. Ano, K. Kano, S. Yamabe, Inorg. Chem., 1991, 30, 3843; (d) H. A. Nieuwenhuis, J. G. Haasnoot, R. Hage, J. Reedijk, T. L. Snoeck, D. J. Stufkens, J. G. Vos, Inorg. Chem., 1991, 30, 48; (e) T. Kojima, K. Hayashi, Y. Matsuda, Inorg. Chem., 2004, 43, 6793; (f) H. Sun, M. Wang, K. Jin, C. Ma, R. Zhang, L. Sun, Eur. J. Inorg. Chem., 2007, 4128; (g) T. Ayers, N. Caylor, G. Ayers, C. Godwin, D. J. Hathcock, V. Stuman, S. J. Slattery, Inorg. Chim. Acta, 2002, 328, 33; (h) M.-K. Tsai, J. Rochford, D. E. Polyansky, T. Wada, K. Tanaka, E. Fujita, J. T. Muckerman, Inorg. Chem., 2009, 48, 4372.

9 (a) P. Steenwinkel, D. M. Grove, N. Veldman, A. L. Spek, G. van Koten, Organometallics, 1998, 17, 5647; (b) M. Gagliardo, H. P. Dijkstra, P. Coppo, L. De Cola, M. Lutz, A. L. Spek, G. P. M. van Klink, G. van Koten, Organometallics, 2004, 23, 5833; (c) M. Gagliardo, P. A. Chase, M. Lutz, A. L. Spek, F. Hart, R. W. A. Havenith, G. P. M. van Klink, G. van Koten, Organometallics, 2005, 24, 4553; (d) S. Ott, M. Borgström, L. Hammarström, O. Johansson, Dalton Trans., 2006, 1434; (e) T. Koizumi, T. Tomon, K. Tanaka, Organometallics, 2003, 22, 970; (f) T. Koizumi, T. Tomon, K. Tanaka, Bull. Chem. Soc. Jpn., 2003, 76, 1969.

10 (a) K. Lashgari, M. Kritikos, R. Norrestam, T. Norrby, Acta Cryst., 1999, C55, 64; (b) S. Pyo, E. Pérez-Cordero, S. G. Bott, L. Echegoyen, Inorg. Chem., 1999, 38, 3337.

11 (a) C. M. Hartshorn, P. J. Steel, Organometallics, 1998, 17, 3487; (b) J. -P. Sutter, S. L. James, P. Steenwinkel, T. Karlen, D. M. Grove, N. Veldman, W. J. J. Smeets, A. L. Spek, G. van Koten, Organometallics, 1996, 15, 941; (c) P. Dani, T. Karlen, R. A. Gossage, W. J. I. Smeets, A. L. Spek, G. van Koten, J. Am. Chem. Soc., 1997, 119, 11317.

12 (a) A. D. Ryabov, V. S. Sukharev, L. Alexandrova, R. Le Lagadec, M. Pfeffer, Inorg. 
Chem., 2001, 40, 6529; (b) S. Maeda, T. Koizumi, T. Yamamoto, K. Tanaka, T. Kanbara, J. Organomet. Chem., 2007, 692, 5495; (c) J. P. Sauvage, J. P. Collin, J. C. Chambron, S. Guillerez, C. Coudret, V. Balzani, F. Barigelletti, L. De Cola, L. Flamigni, Chem. Rev., 1994, 94, 993.

13 I. Kaljurand, A. Kutt, L. Soovali, T. Rodima, V. Maemets, I. Leito, I. A. Koppel, J. Org. Chem., 2005, 70, 1019.

14 Gaussian 03, Revision D.01, M. J. Frisch, G. W. Trucks, H. B. Schlegel, G. E. Scuseria, M. A. Robb, J. R. Cheeseman, J. A. Montgomery, Jr., T. Vreven, K. N. Kudin, J. C. Burant, J. M. Millam, S. S. Iyengar, J. Tomasi, V. Barone, B. Mennucci, M. Cossi, G. Scalmani, N. Rega, G. A. Petersson, H. Nakatsuji, M. Hada, M. Ehara, K. Toyota, R. Fukuda, J. Hasegawa, M. Ishida, T. Nakajima, Y. Honda, O. Kitao, H. Nakai, M. Klene, X. Li, J. E. Knox, H. P. Hratchian, J. B. Cross, V. Bakken, C. Adamo, J. Jaramillo, R. Gomperts, R. E. Stratmann, O. Yazyev, A. J. Austin, R. Cammi, C. Pomelli, J. W. Ochterski, P. Y. Ayala, K. Morokuma, G. A. Voth, P. Salvador, J. J. Dannenberg, V. G. Zakrzewski, S. Dapprich, A. D. Daniels, M. C. Strain, O. Farkas, D. K. Malick, A. D. Rabuck, K. Raghavachari, J. B. Foresman, J. V. Ortiz, Q. Cui, A. G. Baboul, S. Clifford, J. Cioslowski, B. B. Stefanov, G. Liu, A. Liashenko, P. Piskorz, I. Komaromi, R. L. Martin, D. J. Fox, T. Keith, M. A. Al-Laham, C. Y. Peng, A. Nanayakkara, M. Challacombe, P. M. W. Gill, B. Johnson, W. Chen, M. W. Wong, C. Gonzalez, and J. A. Pople, Gaussian, Inc., Wallingford CT, 2004.

15 Gauss View, Version 4.1, R. Dennington II, T. Keith and J. Millam, Semichem, Inc., Shawnee Mission, KS, 2007.

16 (a) R. Le Lagadec, L. Alexandrova, H. Estevez, M. Pfeffer, V. Laurinavičius, J. 
Razumiene, A. D. Ryabov, Eur. J. Inorg. Chem., 2006, 2735; (b) V. S. Soukharev, A. D. Ryabov, E. Csöregi, J. Organomet. Chem., 2003, 668, 75; (c) I. S. Alpeeva, V. S. Soukharev, L. Alexandrova, N. V. Shilova, N. V. Bovin, E. Csöregi, A. D. Ryabov, I. Y. Sakharov, J. Biol. Inorg. Chem., 2003, 8, 683.

17 E. C. Constable, A. M. W. C. Thompson, D. A. Tocher, M. A. M. Daniels, New J. Chem., $1992,16,855$.

18 Crystal Structure: Crystal Analysis Package, Rigaku and Rigaku/MSC, 2000-2006. 
a Chemical Resources Laboratory, Tokyo Institute of Technology, 4259 Nagatsuta, Midori-ku, Yokohama, Kanagawa 226-8503, Japan.

${ }^{b}$ Institute for Molecular Science, Department of Life and Coordination-Complex Molecular Science, 5-1 Higashiyama, Myodaiji, Okazaki, Aichi 444-8787, Japan

${ }^{c}$ Tsukuba Research Center for Interdisciplinary Materials Science (TIMS), University of Tsukuba, 1-1-1 Tennodai, Tsukuba 305-8573, Japan

${ }^{d}$ Graduate School of Pure and Applied Sciences, University of Tsukuba, 1-1-1 Tennodai, Tsukuba 305-8573, Japan

Electronic supplementary (ESI) available: The ORTEP drawing of 2, CV curves of $\mathbf{5}$ and 5 with DBU (0.5-5.0 mol equiv), and ${ }^{1} \mathrm{H}-\mathrm{NMR}$ spectra of $\mathbf{1}, \mathbf{1}$ with 2 mol equiv of $\mathrm{NEt}_{3}$ and that of DBU, Fig. S1-S3 and Table S1. For ESI and crystallographic data for $\mathbf{1}$ and 2 in CIF format see DOI:XXXXXXXXX 
Table 1. Selected bond lengths $(\AA)$ and angles $\left(^{\circ}\right)$ of $\mathbf{1}$.

\begin{tabular}{crcr}
\hline Ru1 - S1 & $2.3707(19)$ & $\mathrm{Ru} 1-\mathrm{S} 2$ & $2.376(2)$ \\
$\mathrm{Ru} 1-\mathrm{C} 1$ & $2.027(8)$ & $\mathrm{Ru} 1-\mathrm{N} 3$ & $2.100(7)$ \\
$\mathrm{Ru} 1-\mathrm{N} 4$ & $2.056(6)$ & $\mathrm{Ru} 1-\mathrm{N} 5$ & $2.112(8)$ \\
$\mathrm{C} 7-\mathrm{S} 1$ & $1.730(8)$ & $\mathrm{C} 8-\mathrm{S} 2$ & $1.736(8)$ \\
$\mathrm{C} 7-\mathrm{N} 1$ & $1.346(8)$ & $\mathrm{C} 3-\mathrm{N} 2$ & $1.357(10)$ \\
& & & $82.3(2)$ \\
$\mathrm{C} 1-\mathrm{Ru} 1-\mathrm{S} 1$ & $82.6(2)$ & $\mathrm{C} 1-\mathrm{Ru} 1-\mathrm{S} 2$ & $172.4(2)$ \\
$\mathrm{C} 1-\mathrm{Ru} 1-\mathrm{N} 3$ & $97.4(3)$ & $\mathrm{C} 1-\mathrm{Ru} 1-\mathrm{N} 4$ & $163.96(6)$ \\
$\mathrm{C} 1-\mathrm{Ru} 1-\mathrm{N} 5$ & $106.4(3)$ & $\mathrm{S} 1-\mathrm{Ru} 1-\mathrm{S} 2$ & $91.43(16)$ \\
$\mathrm{S} 1-\mathrm{Ru} 1-\mathrm{N} 3$ & $93.80(17)$ & $\mathrm{S} 1-\mathrm{Ru} 1-\mathrm{N} 4$ & $93.28(18)$ \\
$\mathrm{S} 1-\mathrm{Ru} 1-\mathrm{N} 5$ & $90.26(17)$ & $\mathrm{S} 2-\mathrm{Ru} 1-\mathrm{N} 3$ & $89.06(18)$ \\
$\mathrm{S} 2-\mathrm{Ru} 1-\mathrm{N} 4$ & $104.10(16)$ & $\mathrm{S} 2-\mathrm{Ru} 1-\mathrm{N} 5$ & $156.2(2)$ \\
$\mathrm{N} 3$ - Ru1-N4 & $78.3(2)$ & $\mathrm{N} 3-\mathrm{Ru} 1-\mathrm{N} 5$ & \\
$\mathrm{~N} 4-\mathrm{Ru} 1-\mathrm{N} 5$ & $78.2(2)$ & & \\
\hline
\end{tabular}


Table 2. Electrochemical data of Ru complexes

$$
E_{1 / 2} / \mathrm{V}^{a}
$$

\begin{tabular}{lcc} 
Complex & $\mathrm{Ru}(\mathrm{III}) / \mathrm{Ru}(\mathrm{II})$ & Ligand $^{0 /-}$ \\
\hline $\mathbf{1}$ & 0.028 & -2.365 \\
$\mathbf{2}$ & 0.088 & $-2.326^{b}$ \\
{$[\mathrm{Ru}(\mathrm{NCN})(\mathrm{tpy})]^{+c}$} & -0.178 & -2.031 \\
{$[\mathrm{Ru}(\mathrm{PCP})(\mathrm{tpy})]^{+c}$} & 0.167 & -1.946 \\
\hline
\end{tabular}

${ }^{a}$ Measured in an acetonitrile solution of $\left[(n-\mathrm{Bu})_{4} \mathrm{~N}\right]\left[\mathrm{PF}_{6}\right](0.1 \mathrm{M})$. Potentials in $\mathrm{V}$ vs. $\mathrm{Fc}^{+} / \mathrm{Fc}$.

${ }^{b}$ Irreversible reduction peak potential.

${ }^{c}$ Ref. 9b 
Table 3. Electrochemical data of Ru complexes in the presence of base

\begin{tabular}{|c|c|c|}
\hline \multirow[b]{2}{*}{ Complex } & \multicolumn{2}{|l|}{$E_{1 / 2} / \mathrm{V}^{a}$} \\
\hline & $\mathrm{Ru}(\mathrm{III}) / \mathrm{Ru}(\mathrm{II})$ & Ligand $^{0 /-}$ \\
\hline 1 & 0.028 & -2.365 \\
\hline $\mathbf{1}+\mathrm{NEt}_{3}{ }^{b}(\mathbf{3})$ & -0.226 & $-^{c}$ \\
\hline $\begin{array}{l}\text { 1+DBU } \\
\text { (4) }\end{array}$ & -0.692 & $-^{c}$ \\
\hline 2 & 0.088 & $-2.326^{d}$ \\
\hline $2+\mathrm{NEt}_{3}{ }^{b}$ & -0.122 & $-^{c}$ \\
\hline $2+\mathrm{DBU}^{b}$ & -0.460 & $-^{c}$ \\
\hline 5 & -0.055 & $-1.992^{d},-2.333^{d}$ \\
\hline
\end{tabular}

${ }^{a}$ Measured in an acetonitrile solution of $\left[(n-\mathrm{Bu})_{4} \mathrm{~N}\right]\left[\mathrm{PF}_{6}\right](0.1 \mathrm{M})$. Potentials in $\mathrm{V} v s$. $\mathrm{Fc}^{+} / \mathrm{Fc}$.

${ }^{b}$ Addition of 2.00 mol equiv of base.

${ }^{c}$ Not measured.

${ }^{d}$ Irreversible reduction peak potential(s). 
Table 4. Selected calculated singlet excited-state transitions for $\mathbf{1}$.

\begin{tabular}{cccc}
\hline Complex & $\begin{array}{c}\text { Wavelength } \\
(\mathbf{n m})\end{array}$ & $\begin{array}{c}\text { Oscillator } \\
\text { strength }\end{array}$ & $\begin{array}{c}\text { Assignment (\% of major transition } \\
\text { contributing to the band) }\end{array}$ \\
\hline $\mathbf{1}$ & 474 & 0.0967 & $\mathrm{HOMO}-2 \rightarrow$ LUMO $(55 \%)$ \\
& 401 & 0.0759 & $\mathrm{HOMO}-1 \rightarrow \mathrm{LUMO}+3(71 \%)$ \\
\hline
\end{tabular}


Table 5. Crystal data and details of the structure refinements for $\mathbf{1} \cdot \mathrm{Et}_{2} \mathrm{O}$.

\begin{tabular}{|c|c|}
\hline Formula & $\mathrm{C}_{41} \mathrm{H}_{40} \mathrm{ON}_{5} \mathrm{~S}_{2} \mathrm{RuPF}_{6}$ \\
\hline Molecular Weight & 928.95 \\
\hline Crystal System & Triclinic \\
\hline Space Group & $P-1$ (No. 2) \\
\hline$a(\AA)$ & $11.75(2)$ \\
\hline$b(\hat{A})$ & $13.87(3)$ \\
\hline$c(\AA ̊)$ & $14.74(3)$ \\
\hline$\alpha\left({ }^{\circ}\right)$ & $77.43(2)$ \\
\hline$\beta\left({ }^{\circ}\right)$ & $86.74(3)$ \\
\hline$\gamma\left({ }^{\circ}\right)$ & 64.02(4) \\
\hline$V\left(\AA^{3}\right)$ & $2106.4(68)$ \\
\hline$Z$ & 2 \\
\hline$\mu\left(\mathrm{cm}^{-1}\right)$ & 5.745 \\
\hline$F(000)$ & 948.00 \\
\hline$D_{\text {calc }}\left(\mathrm{g} \mathrm{cm}^{-3}\right)$ & 1.465 \\
\hline No. total reflns & 18850 \\
\hline No. unique reflns & 8913 \\
\hline No. variables & 554 \\
\hline$R_{l}^{a}$ & 0.0726 \\
\hline$R_{w}{ }^{b}$ & $0.1048^{c}$ \\
\hline
\end{tabular}

${ }^{a} R_{1}=\Sigma|| F_{\mathrm{o}}|-| F_{\mathrm{c}}|/ \Sigma| F_{\mathrm{o}} \mid$ for $I>2.0 \sigma(I)$ data.

${ }^{b} R_{w}=\Sigma\left[w\left(F_{\mathrm{o}}^{2}-F_{\mathrm{c}}^{2}\right)^{2} / \Sigma w\left(F_{\mathrm{o}}{ }^{2}\right)^{2}\right]^{1 / 2}$. Weighting scheme $1 /\left[0.0059 F_{\mathrm{o}}{ }^{2}+1.0000 \sigma\left(F_{\mathrm{o}}{ }^{2}\right)\right]$. 


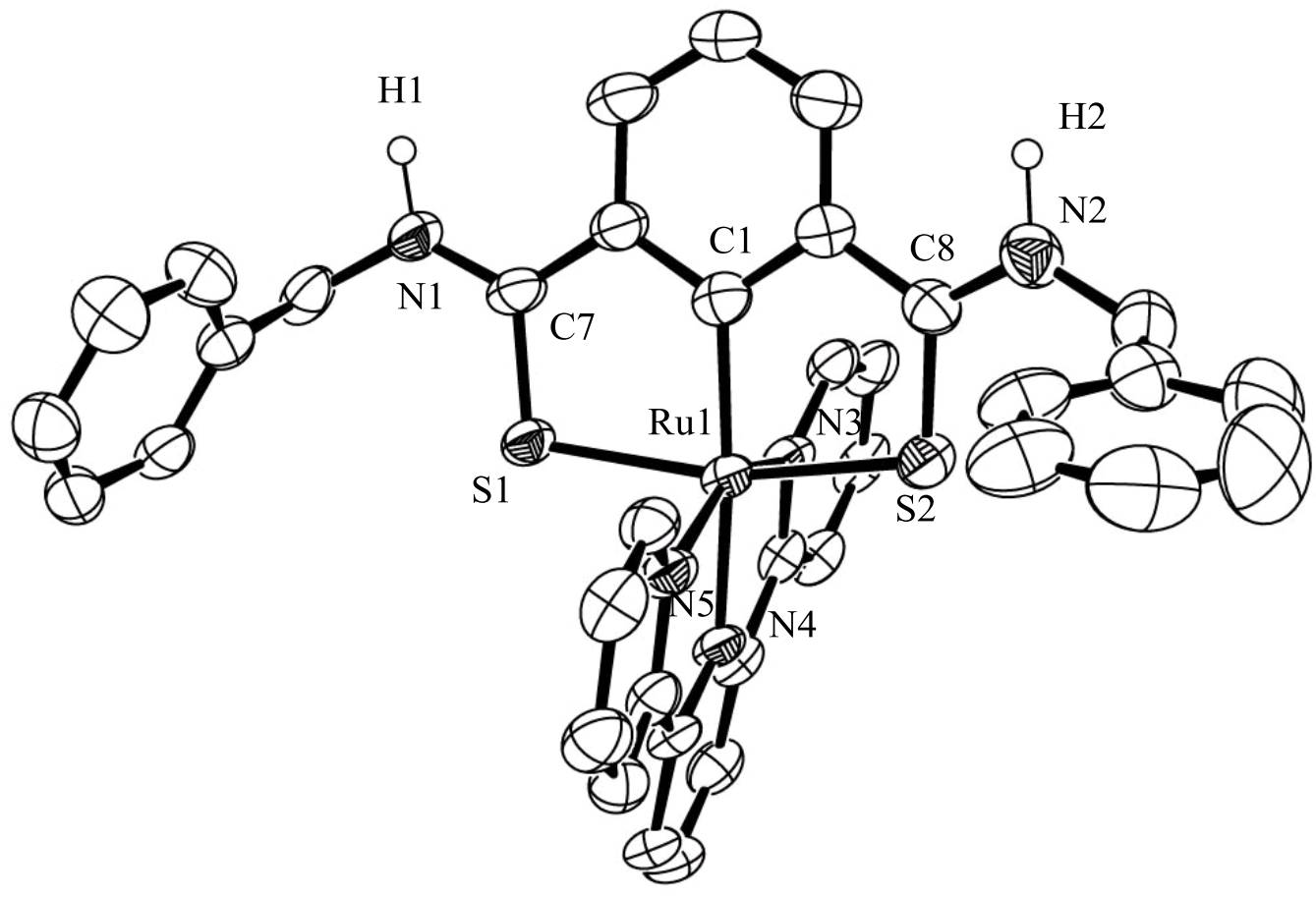

Fig. 1 Molecular structure of 1 with thermal ellipsoids drawn at the 50\% probability level. Hydrogen atoms except $\mathrm{H}(1)$ and $\mathrm{H}(2), \mathrm{a} \mathrm{PF}_{6}{ }^{-}$anion, and a solvated diethyl ether molecule are omitted for simplicity. 


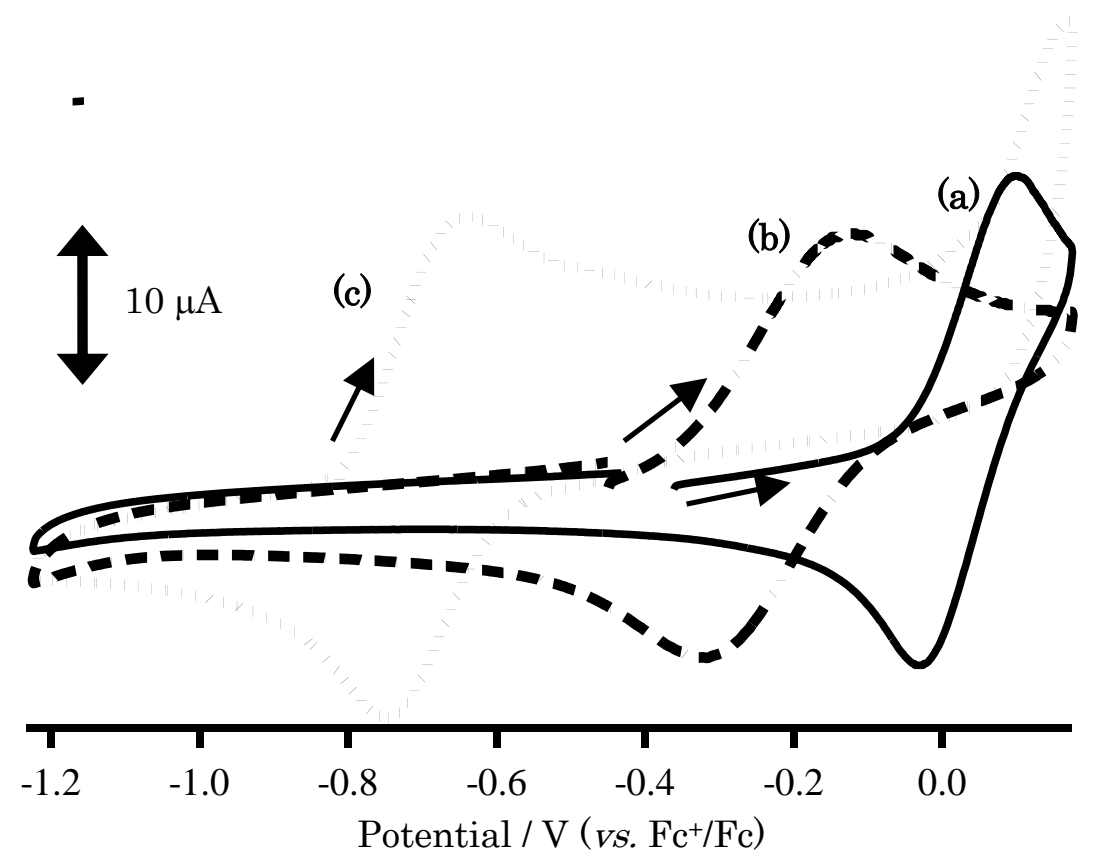

Fig. 2 Changes in the cyclic voltammogram of $\mathbf{1}(1 \mathrm{mM})$ caused by addition of base in $\mathrm{CH}_{3} \mathrm{CN}$ containing $\left[(n-\mathrm{Bu})_{4} \mathrm{~N}\right]\left[\mathrm{PF}_{6}\right](0.1 \mathrm{M})$ under $\mathrm{N}_{2}$ at sweep rate of $100 \mathrm{mV} \mathrm{s}^{-1}$ : (a) $\mathbf{1}$, (b) 1 with 2 mol equiv of $\mathrm{NEt}_{3}$, and (c) 1 with 2 mol equiv of DBU. 
(a)

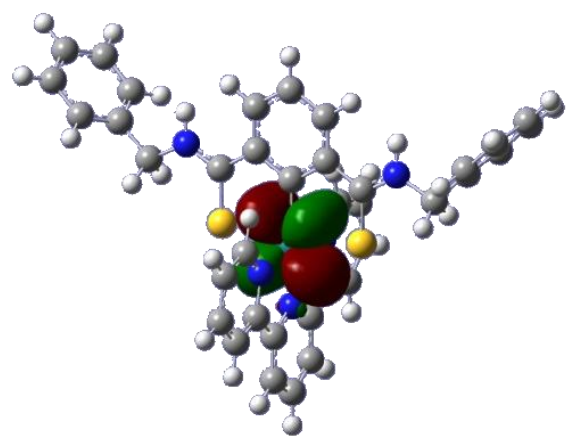

(c)

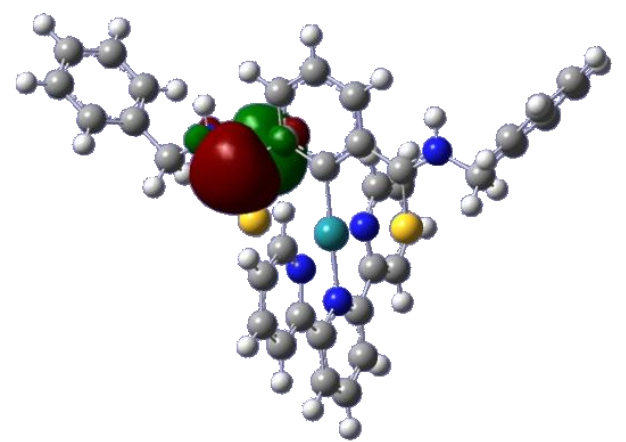

(b)

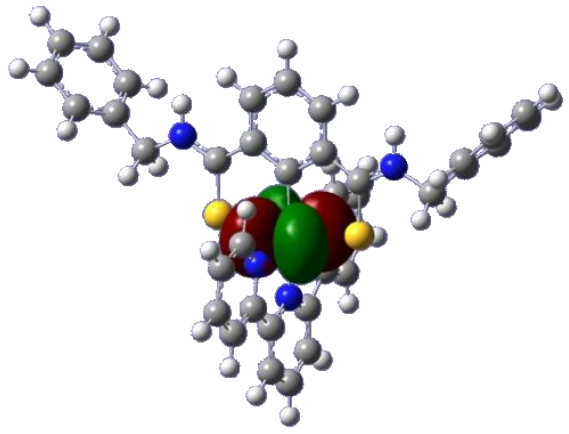

(d)

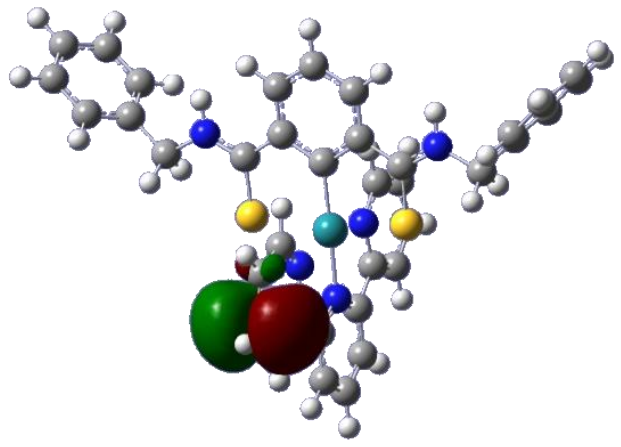

Fig. 3. Calculated (a) HOMO -1, (b) HOMO -2, (c) LUMO, and (d) LUMO + 3 orbitals of 1. 


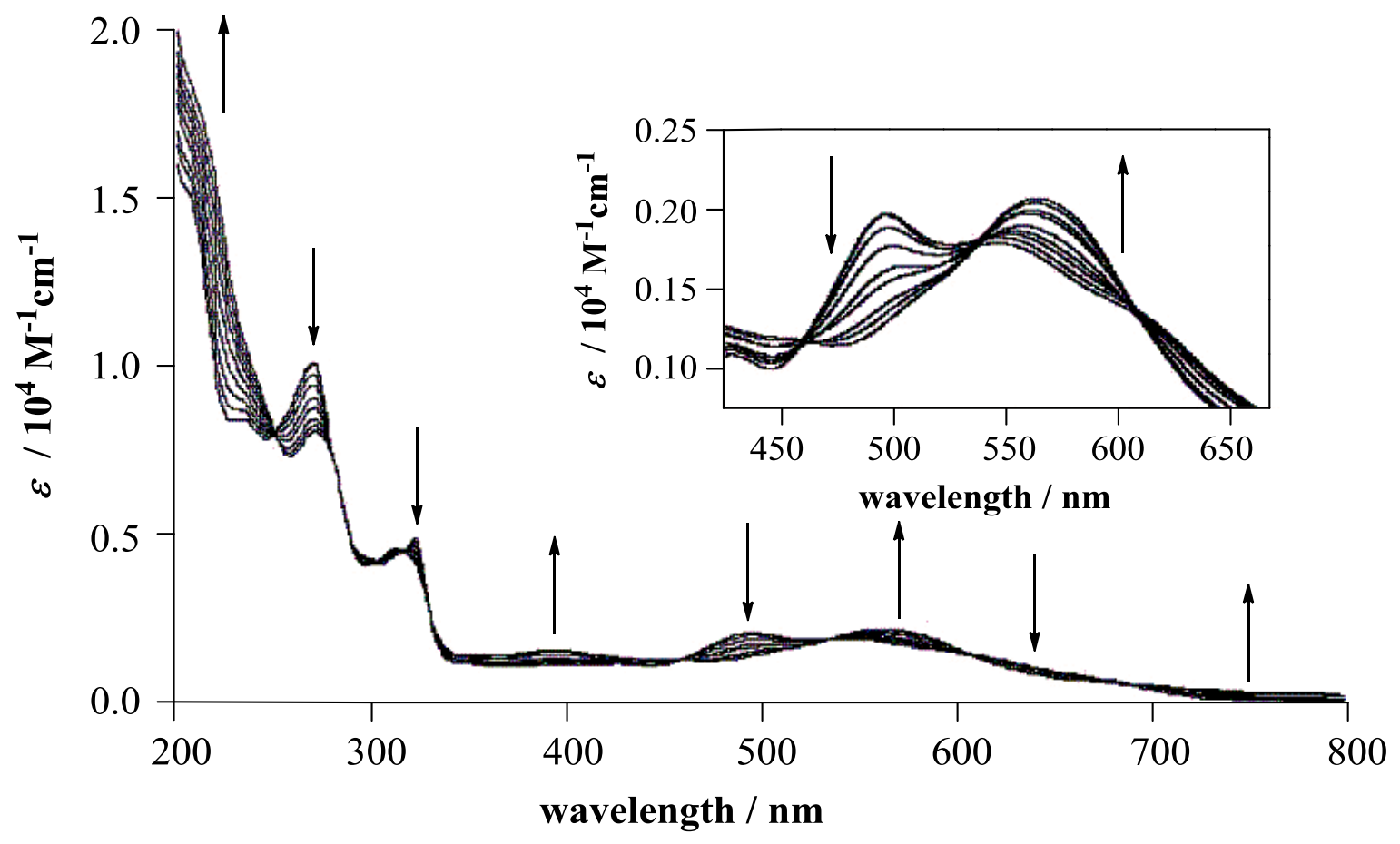

Fig. 4 Changes in the absorption spectrum of $1\left(2.5 \times 10^{-5} \mathrm{M}\right)$ caused by addition of DBU in $\mathrm{CH}_{3} \mathrm{CN}$ under $\mathrm{N}_{2}$. The inset shows the range of $400-700 \mathrm{~nm}$. 


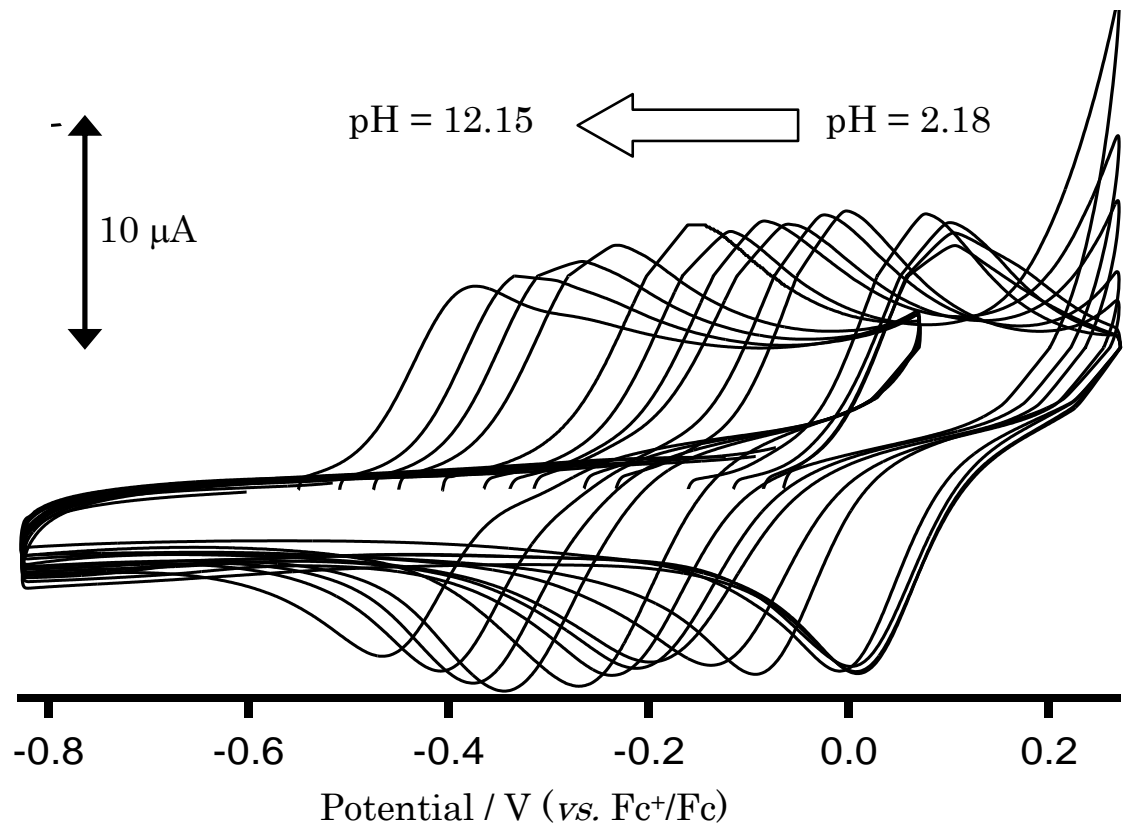

Fig. 5 pH-dependent redox couple of $\mathrm{Ru}(\mathrm{III}) / \mathrm{Ru}(\mathrm{II})$ for $\mathbf{1}$ in a $\mathrm{CH}_{3} \mathrm{CN} /$ Britton-Robinson buffer $(1: 1 \mathrm{v} / \mathrm{v})$ solution. 


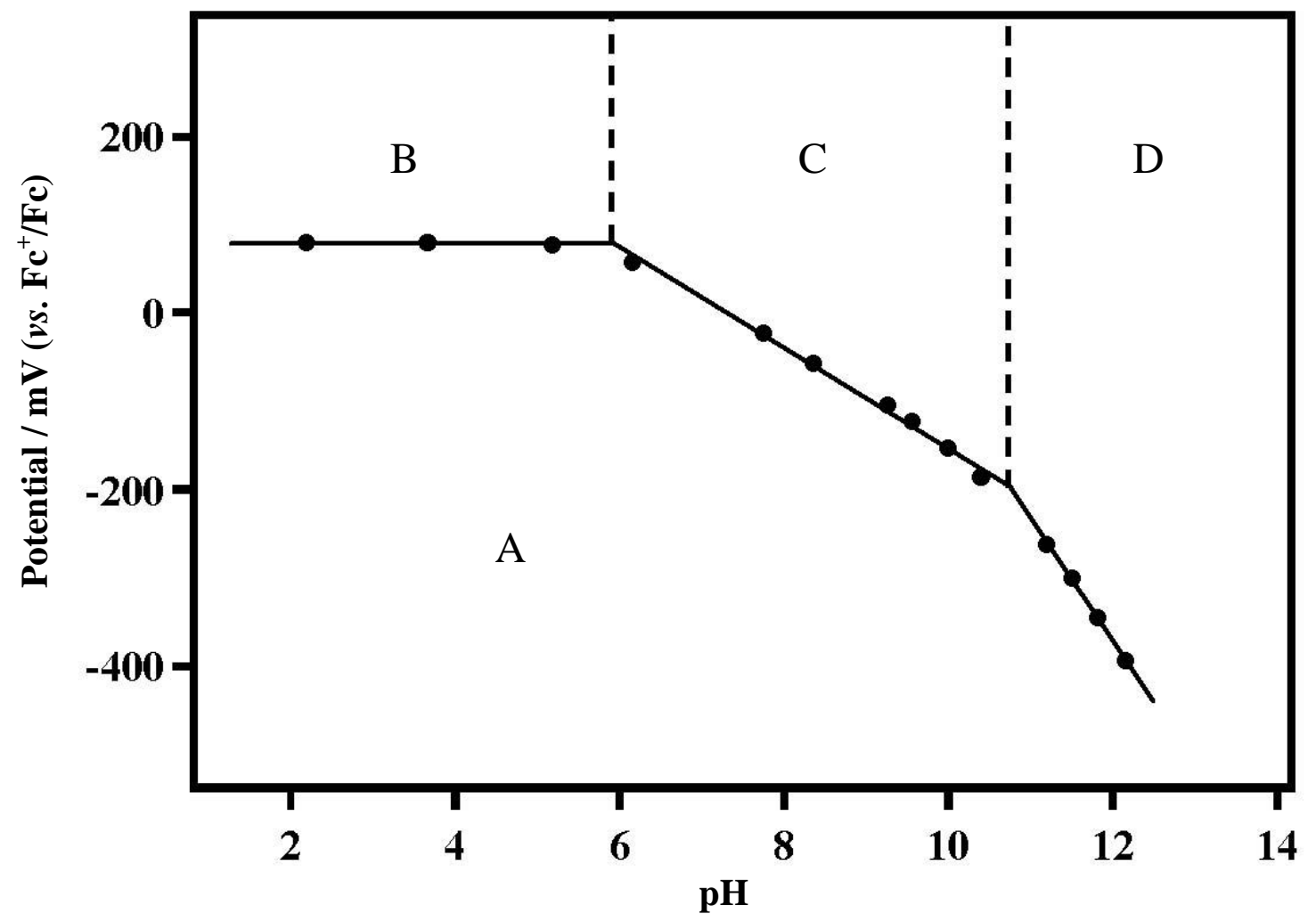

Fig. 6 Pourbaix diagram of the titration of 1 in $\mathrm{CH}_{3} \mathrm{CN} /$ Britton-Robinson buffer $(1: 1 \mathrm{v} / \mathrm{v})$. Each region represents the following species: (A) $\left[\mathrm{Ru}(\mathrm{II}) \mathrm{LH}_{2}\right]^{+} ;(\mathrm{B})\left[\mathrm{Ru}(\mathrm{III}) \mathrm{LH}_{2}\right]^{2+}$; (C) $[\mathrm{Ru}(\mathrm{III}) \mathrm{LH}]^{+}$; (D) $[\mathrm{Ru}(\mathrm{III}) \mathrm{L}]^{0}$. 